\title{
Royal Attire, Ceremonialism, and Performing Arts in the Kraton of Yogyakarta
}

\author{
R. M. Pramutomo (Corresponding author) \\ Indonesian Institute of the Art Surakarta \\ Indonesia \\ E-mail: rmpram60@gmail.com
}

Received: February 27, 2020 Accepted: March 31, 2020 Published: June 19, 2020

doi:10.5296/ijch.v7i1.16557 URL: https://doi.org/10.5296/ijch.v7i1.16557

\begin{abstract}
Royal attire aspect as part of the process of fashion and identity is an interesting phenomenon for a study. Especially if that aspect is then intended as a special element in relation to the events of ceremonialism and performance art in Yogyakarta Palace. In this presentation, a phenomenon which is closely related to the development of attires in the event of ceremonialism and performance art in the palace. Ceremonialism itself is a formal pattern designed for strategic interests which is combined in a compromise manner through the presentation of performance art. As stored in archival and document sources, there are always a number of formal standard patterns applied in ceremonialism. The best sources that are still being treated in the Sultan's Palace are manuscript records such as planners, budgels, pranatan and so on. In addition, through the archival studies approach, it is also known that the pattern of formal memory is also well stored among society record keepers as an oral tradition. This archival studies approach then limits in the area of fashion studies in a variety of standard formal patterns when the Yogyakarta Kraton performing arts perform certain ceremonies.
\end{abstract}

Keywords: Ceremonialism, Attires, Performing arts, Kraton

\section{Introduction}

The introductory part of this article will be preceded by an understanding of ceremonialism in a special sense. The definition of ceremonialism in question is the forms of tradition that are the impact of cultural contact with Europeans, especially in the period of Dutch colonialism. Ceremonialism itself will first refer to Clifford Geertz's description when looking at the phenomenon of colonialism in the late XVIII century to the beginning of the XIX century.In his view, ceremonialism, according to Geertz, is assumed as a pattern of regularity or planned 
formality in an indigenous and political state. The top of the hierarchy is the status of adat as well as the political status inherent in the king. This then gave birth to a theater state view according to Geertz (Geertz; 1980: 249-253). This was then conceived of as an indigenous state as well as a political state. Coincidentally this phenomenon was captured by Geertz when doing fieldwork in the kingdoms of Bali in the early nineteenth century.

In the Javanese context, something that resembles the extension of an indigenous and political state was triggered by cultural contact with the colonial world during the late XVIII century. Several kingdoms in Java after the breakup of the Islamic Mataram kingdom in 1756 established extensive relations with the Dutch colonial. Specifically, this article examines the Yogyakarta Kingdom that could not be separated from the impact of cultural contact with colonial Dutch until the early nineteenth century. (before the arrival of the British in 1811). The initial momentum of a formal pattern of ceremonialism actually became interesting when the process of transition of Dutch colonialism to Britain in the early nineteenth century. If traced back to the end of the reign of Sultan Hamengku Buwana II (the first reign, namely 1792-1812), some of the designations referred to in the statement of kangjeng éyang and the like have not yet emerged as a form of custom. (Note 1)

In turn, the impact of ceremonialism becomes one of the main assumptions for the start of the fashion process in the dress code procedures involved. This impact began to be carried out intensively during the post-Sultan Hamengku Buwana IV era (1816-1823). The observation of Margana in the Surakarta and Yogyakarta Kraton (1769-1874) proves this. It was stated in the book, that until the transition of the second Sultan's government to the administration of government by Kangjeng Gusti (Kangjeng Raja or the Crown Prince who would later become Hamengku Buwana III), clear descriptions of the traditions of visiting each other with various forms of performance banquets and party event. (Note 2) Indications of the pattern of interaction above, it is very possible to occur in the transfer of power of British colonialism back to the era of Dutch colonialism.

\section{Discussion}

Referring to this transitional era, the tendency of performing arts and ceremonialism practices has been prevalent in the reign of Sultan Hamengku Buwana IV (1816-1823). This is especially since the Regent of Japan Ngabèhi Sumadipura held the post of Patih with the title Danureja III. This Patih was one of the elite palace bureaucrats who graduated the most Western ceremonial and protocol style until the onset of the Javanese War (Dipanegara War 1825-1830). (Note 3) Intersection between performing arts and protocol ceremonies in turn manifested greater influence during the reign of the next Sultan until later in the era of Sultan Hamengku Buwana VII (1877-1921). Some sources even informed the visit of guests from other kingdoms in the Palace, often an extension of the cultural interaction that occurred at that time.

In 1893 for example, the seventh Sultan helped approve the existence of the first horse race started in Shawwal. (Note 4) In addition to the sports function emphasized in this race, gambling elements are also announced to enliven the race horse betting market. Information about other important events is also described in the Serat Babad Momana, and in some 
palace archives during the seventh Sultan's reign. (Note 5) In addition to visiting forms that heighten the frequency of Western cultural interaction with Java in the palace environment, other forms of routine protocol ceremonies such as tedhak loji have become a norm which is a continuation of the post-reign of the fourth Sultan.

The need to reveal a tedhak loji phenomenon as a new form of tradition in the context of the Yogyakarta Palace is a historical fact. The anthropological view of behavior, according to Desmond Morris, needs to be put forward as a conceptual basis in explaining the nature of loji in the context of civilization. Morris revealed a submissive behavior as another way to be modest. (Note 6) In the context of Yogyakarta Palace the pattern of submissive behaviors does not mean to lower themselves as a form of response. The historical fact is in the aesthetic response that is shown by a pattern of status displays by involving dress behavior that is updated according to taste compromise. Therefore, in Morris's reference, the pattern of dress is indicated by three types, namely clothing for comfort, clothing for modesty, and clothing for display. (Note 7) For this reason the aspect of Royal Attires as a fashion process is closely related to aesthetic behavior, because in it there is an aesthetic response that is part of the measurements according to its contextuality.

\section{Royal Attire and the Process of Fashion into the Ceremony of Garebeg, Tedhak Loji, and Wayang Wong}

The definition of 'drama ceremonialism' in this case is borrowed from the term Geertz challenging the situation of 19th century Bali which shows the aesthetic image of the essential cultural forms and cultural resources. In the early part of his assumption, Geertz saw power in Bali exercised in such a manner directed towards performances, ceremonies, towards dramatization in public from the main obsessions of Balinese culture. A degree of social status and pride. He called Bali a theater state in which there were kings and princes were impresario, priests were directors, farmers were supporting actors, stylists and spectators. (Note 8)

A direct explanation from Geertz indicates the purpose of the ceremonies and ceremonial forms of the ritual is not as an achievement of political goals. Ceremonialism of the palace (according to the term used by Geertz) is the driving force of palace politics, and the mass ritual is not a tool to support the state, but the state as a tool to hold a mass ritual. Geertz briefly emphasized the power to serve ceremonies, not ceremonies to serve powers. (Note 9) However, Geertz also hinted that the position of the relations referred to in the aesthetic image indicated the 'drama of ceremonialism' factor in the concept of a 19th-century theater in Bali.

Geertz explicitly explained the status of the priests before the 19th-century Balinese kings like an emblem, or even as a decoration of the king himself. In this assumption, its position is in line with regalia. (Note 10) Therefore, almost every ceremonial procession is also an exhibition of sacredness. The same thing is also shown in the king's relationship with the material world. The term 'mandruwe' which means the possessive right of a king includes all things that belong to the 'king' is no exception. (Note 11) The description is measured hierarchically in the understanding of the exemplary of the center. The sideways status 
pattern is a form of imitation of its center. The ideal king is a king who is protected and has the love of god. The good knights are in protection and have the love of the king. The good farmers are in protection and have a love of knights. Thus spiritually this dimension reaches the sacred space, as the nature of the possessive relationship in the ownership of an adat village is an ideal imitation of an indigenous state. (Note 12) In turn, as in traditional villages, that the customary state bases its life not solely on the social and economic dimensions, but on the scale of religiosity. This view in the relationship between the status of kings and priests as well as kings and the material world is able to image a collective ceremonial 'drama' that touches sacred spaces.

Comparing the similarities in the forms of 'drama of ceremonialism' in Yogyakarta Palace in the early 19th century, it does not have to be comparative in meaning. The similarity shown by the customary events at the Yogyakarta Palace can be observed during the reign of Sultan Hamengku Buwana IV. (Note 13) The presentation in this section will begin with three types of traditional events, namely Grebeg, tedhak loji, and Wayang Wong performances.

At least three types of traditional events can begin with the tradition of the Grebeg ceremony. Grebeg Ceremony is a sadaqah ceremony of the Sultan of Yogyakarta to commemorate Islamic holidays, namely Grebeg Syawal, Grebeg Besar, and Grebeg Mulud. The form of alms procession is manifested by the symbol of hajad dalem paredèn or the form of mountain food. During the ceremony there was a procession that was escorted by a number of servants in the palace totaling 10 bregada or 10 flag units including Wirabraja, Dhaèng, Patangpuluh, Jagakarya, Prawiratama, Nyutra, Ketanggung, and Mantrijero who were soldiers of the Yogyakarta Palace, and two bregada another, namely, Bugis and Surakarsa were soldiers of Kepatihan Danurejan, and soldiers of Kadipatèn Anom. (Note 14) Traditional sources from Babad Ngayogyakarta recorded that the Grebeg event had taken place since the time of Sultan Hamengku Buwana I (1755-1792) reigned in Yogyakarta. (Note 15) During the time of the fourth Sultan, the procession of the palace servants still approached the events of the procession during the first Sultan. Each unit was prepared by the Regent of Kumendam in Alun-alun selatan before accompanying the hajad dalem paredèn.

During the time of the fourth Sultan, the procession of the palace servants still approached the events of the procession during the first Sultan. Each unit was prepared by the Regent of Kumendam in Alun-alun selatan before accompanying the hajad dalem paredèn.

Looking at a form of the Grebeg procession from the time of the first Sultan to the fourth Sultan was very tiring. Preparation since Alun-Alun Selatan and until finally heading to Alun-Alun Utara before entering the Great Mosque takes no short time. If from 06.00 the entire bregada has been prepared at Alun-alun Selatan, then at the end of the procession at Alun-alun Utara it will most likely not be finished at 11.00 noon. So almost half a day of the Grebeg procession has just entered its final stage before the hajad dalem paredèn is prayed for and fought over in the Great Mosque.

This is a status display full of 'drama' because there are certain parts of each processional stop involving various attractions from each entity. (Note 16) Until the time of the Sultan the fourth form of the procession that displayed an aspect of the grandeur of the status display 
was carried out since the Sultan had an audience in the Siti Hinggil Ward, where a number of bregada began to pay their respects and entered the Kemandungan gate (the southernmost gate in the Yogyakarta Palace main building). Then the Sultan accompanied by all his skills received respect when heading to the Wards. Back in this area a number of bregada paid their respects around the Sultan's throne. After the Sultan received his respects in the Kemerdekaan Ward, he immediately entered the central palace in the Kencana Ward facing east, accompanied by a number of palace performances. The soldiers immediately made a procession of respect by entering the central palace walking north to the Sri Manganti Ward. Then exit through the Sri Manganti gate past the Pancaniti Ward and immediately go up to the Brajanala gate towards Siti Hinggil north.

During receiving honors from a number of bregada, the Sultan was always accompanied by the Yogyakarta Resident and all the Dutch colonial officials. An interesting thing in the status display pattern is that the amparan (throne of the Sultan's feet) is always brought along with the elements of the palace ceremony (which are carried by the courtiers of the Manggung). From the measurement of the construction of the amparation, it is clear that aspects of the competition status can be read in the context of the name of the Sultan's title, sampeyan dalem. (Note 17) If during the Yogyakarta Resident accompanied the sitting position of the Sultan, the position of the Sultan's foot was actually higher than the position of the colonial officials. This implies assumptions that involve competition status which is indicated in the influence of 'pseudoabsolutism' in Yogyakarta Palace. When the Sultan received his respects in northern Siti Hinggil, the pattern of holding hands was always an important part of the state protocol with the Dutch colonial leaders. Spectators in Alun-alun utara attend a mass ritual, but its presence is more important in a factor of state support.

This is what distinguishes the aesthetic situation of 'ceremonial drama' in Yogyakarta with Bali. The ceremony itself as a tool to serve power. The king is not merely an impresario, but the king himself acts as a director. The appearance aspect in various elements of the Grebeg ceremony is an interesting aesthetic situation. At first the appearance aspect was not so much influenced by European 'style'. However, it has been known, that during the reign of Sultan Hamengku Buwana IV there was a change in European design in the fashion of the palace servants. (Note 18) Of course this is one aspect of supporting changes in institutional status of servicemen in the army.

An excerpt can be cited from the manuscript of Ngayugyakarta Pagelaran Number D 34 of the Collection of Widya Budaya, that ingkang Sinuwun kaping sekawan ngersakaken yasa busana kagem busana prajurit ketanggung, mantrijero. (Note 19) According to this evidence that Sultan Hamengku Buwana IV himself wanted to create the dress of an enduring and orderly soldier. These are then described by this source as follows.

.... Kethunipun panji kadamel saking laken cemeng, mawi bulu bulu cemeng, udheng wulung, sikepan lurik ginggang blenggen utawi ketepan, celana laken cemeng, keci ijem mawi setiwel dedamel pedhang cengkle, pengagemipun sresan utawi jajar kethu wacucal tanpa bulu bulu sikepan lugas keci mori pethak mawi setiwel dedamel ipun sepalih senjatasepalih waos.... (Note 20) 
Translate:

(... the design of the head named kethu is made of black laken material, with black feather accessories, waffle motif blangkon, sikulu motif design ginggang blenggen motif or with ketep decoration, black laken trousers, wear attribute named green color using a set for shoe joints lars armed cengkle sword, sergeant clothing or ranks of the head design of the head of the head of the skin without black fur plain design sikepan wearing attributes named keci made of white mori wearing a setiwel lars shoe joints armed with some rifles partially spear).

Evidence of a change in the functional status of servicers' servicemen to ceremonial institution status began with Sultan Hamengku Buwana IV ascending the throne. It is only possible in this way that what the fourth Sultan imagined could still maintain the 'prestige' of political power. This also includes the editorial pattern of Ingkang Rama Kangjeng for the Resident of Yogyakarta becoming a new custom after Sultan Hamengku Buwana IV ascended the throne in 1816.

The same thing was done by the Sultan in a tedhak loji ceremony. This ceremony is a new tradition that allegedly took place in the time of Sultan Hamengku Buwana III (1812-1814). This is based on the traditional source of the Serat Babad Momana which informs the wishes of British Resident John Crawfurd that the renewal of the state protocoll has been adjusted according to the prevailing bureaucratic order. This began with an act of honorary visit between the Resident and the third Sultan. (Note 21)

During the fourth Sultan, because Prince Paku Alam I had a very strong influence on relations with the British during the Resident John Crawfurd, the tedhak loji pattern was developed in the tradition of visiting ceremonies between Dutch colonial officials (power had changed back into the hands of Dutch colonialism) with the Sultan of Yogyakarta. The fourth Sultan, who was known to have mastered various Bedhaya and Srimpi dances, began to bring royal dances to the Tedhak Loji tradition during his reign. Serat Babad Momana also wrote that the fourth Sultan paid little attention to the government bureaucracy controlled by Patih Danureja III. In the end, the Prime minister who was previously the Regent of Japan (formerly Ngabehi Sumadipura) escaped numerous state protocols that were brought by the Dutch colonial officials into the palace. (Note 22) One of the most important aspects of Western (colonial) protocol elements that has been passed is the Sultan's dress code for tedhak loji.

Even in the history of the Sultan's Palace, the fourth Sultan was known as the most 'Western' Sultan among the other Sultans. (Note 23) Sociologically the fourth Sultan was also able to influence elitist values which were demonstrated through changes in dress design in the soldier's territory. What is worn as an official dress, such as groot tenue, for example, will be a reference to the elitist nature of the Sultan's status. In other words what is considered elitist is always based on the will of the king. (Note 24)

The tedhak loji event is another 'ceremonial drama' which was constructed through the state theater stage, but the political nuances presented by the Yogyakarta Palace were very strong. 
If Geertz strengthens his assumption in Bali with the priestly factor as the expansion of customary state space into sacred space, then this is not the case in Yogyakarta. Customary state space in Yogyakarta Palace is a political space that is extended from the battle of status displays. The traditional state as a stage was expanded with symbols attached to the Sultan's peak status, and this was not merely a decoration or an emblem. (Note 25) The name of the title Sultan Sultan is attached to the meaning of the foot's throne to the Sultan's seat for the Sultan's seat. (Note 26) Every tedhak loji ceremony, amparan (J) is always brought along with other palace ceremonies to the official residence of the Resident of Yogyakarta.

The long procession was arranged in such a way as to involve a number of elite traditional royal statuses (princes and Patih and their subordinates). A set of gamelan used for dance accompaniment at the Resident's official residence is also included in the procession of the tedhak loji procession. Besides that, gamelan Pakurmatan (Kodhok Ngorek and Monggang) also participated in the tedhak loji ceremony. As stated by 'Sumaatmaja, Palawija, Dyah Manggung Nata tansah kinanthi 'which means the guardian of the king Sumaatmaja, the Palawija court servants, and the young female palace servants accompanied the king. Sumaatmaja was one of the sections of the Nyutra unit with a taméng weapon and sword always running in front of the king. Palawija is a special courtier who is a symbol of the Sultan's generosity, and usually consists of people with disabilities, cébol, albinos, and various other forms of physical deprivation. The gig is the carrier of the palace ceremony, including amparan (J). This fact also indicates that the king himself acts as an impresario and director.

The presence of the audience throughout the procession tedhak loji as a stage arrangement that serves power. When viewed from the procession, the spectators of the loji occupy an area as wide as the North Square to the north along Pangurakan to the north to the gates of the official residence of the Resident of Yogyakarta.

One more thing that can be explained in a 'ceremonial drama' of an indigenous country in the Sultan's Palace is the Wayang Wong performance. As an elitist art product, Wayang Wong is a very magnificent drama genre. Therefore, when Sultan Hamengku Buwana III fulfilled the wishes of the British colonial officials at the beginning of his reign, his preparations were very detailed. (Note 27) The historical perspective of Wayang Wong asi a dish of colonial leaders has taken place since the time of Hamengku Buwana III. At the time of the Sultan the four traditions of Wayang Wong offerings were not much informed in traditional sources. It's just that the fourth Sultan would pay more attention to the Bedhaya and Srimpi genres. This assumption does not mean that the Wayang Wong drama is not considered at all. It is precisely the evidence from the previous Sultan's time that it showed the detailed aspects of Wayang Wong, so the order of performances in the time of the fourth Sultan was more likely to be heeded.

In light of the high status of Wayang Wong', the setting of the show reflects the neat way of engaging the audience. In view of the real audience in Wayang Wong's is the king himself, who also acts as the real mastermind. Evidence from this explanation, that a dancer would perform the ritual of worship (J) to the Sultan seven times during the performance. The 
seventh worship was performed from the first worship before the dancer entered the performance area. The second show was on the show floor, followed by a jaunt $(\mathrm{J})$ or a squat road leading to the starting point of the dance. The third performance was performed at the starting point of the dance, followed by the gesture of please. The fourth performance is performed at the beginning of the dance. The fifth performance is performed after the final dance. Then the squat dancer performs the sixth worship before leaving the end point of the dance. The seventh worship is the final, performed when the dancer leaves the show floor.

The first and the third and the sixth and seventh acts of worship are the tribute to the Sultan as the true dancer and spectator. When the show was at the top of the Dutch colonial stage, the purpose of worship included aspects of display status. This is because the purpose of worship is to fill the political space of the theater stage of Wayang Wong. The public spectators surrounding the whole site of the Tratag of Kencana Ward are also not just a statement of dramatic attendance. This public audience is also part of the 'drama' of the custom space that has expanded into the political space. The concept of the display status also appears on the throne or Sultan's (J) throne that was on display to the public at that time. From the perspective of the narrative text, the purpose of the dance is clear not to the public. The statement of the sentence is often used as a measure, "... which the law requires.

The statement of the presence of lay audiences or court servants, sitting cross-legged on the sandy courtyard, became a 'drama' of tribute to the Sultan of Yogyakarta during the reign of Hamengku Buwana III to Hamengku Buwana IV, 1812-1823. This is also the factor that distinguishes the aesthetic situation that is presented through the audience aspect. The Sultan's status as a puppeteer is actually comparable to the role of the king as a director in 19 th century Bali. However, the presence of cloud viewers serves a power. The audience may not be as free as the connoisseurs of the performing arts. The audience is only possible to admire the aesthetic situations that arise in the grandeur of the status display. In the Wayang Wong performance, other forms of exhibition can also be observed through the clothes worn by the audience. The lay audience is the biggest audience in this event. They are not allowed to wear clothes, and only clothe. For women must wear a week or back. The Yogyakarta Resident and colonial officials wore official Western-style clothing, while the Sultan's princes and princesses wore traditional clothing (piety, dhestar, clothed, wearing cenéla for the princes, as well as bowed ukel bows, long kebaya and clothed for the princesses of the Sultan). During the reign of the fourth Sultan it was probable that the Sultan himself wore Western-style groot tenue clothing.

However, the most important marker during the fashion exhibition in the Wayang Wong performance was the honor star accessory worn by the Sultan on the left chest. (Note 28) This star is preserved as the official star of each subsequent coronation of the Sultan until now. The fact shows, that every performance of Wayang Wong is a 'drama' gambling of authority. This is a big 'drama' that risked the charismatic and traditional authority of the Sultan's person with rational legal authority that fulfilled the practice of the Dutch colonial bureaucracy at the time. 


\section{Macrothink}

Until this presentation a ceremonialism in the context of the Yogyakarta Palace is a fashion process. Because the process process indicator is a form of signifier, the process mode itself is culturally a form of aesthetic response that prevails in a struggle. Therefore fenomena tedhak loji as a new tradition is actually a cultural product that was born by British colonialism (the Resident John Crawfurd) and eventually became part of the process of mode. Its position in the status display pattern is parallel to the Grebeg ceremony and performing arts events in the Palace.

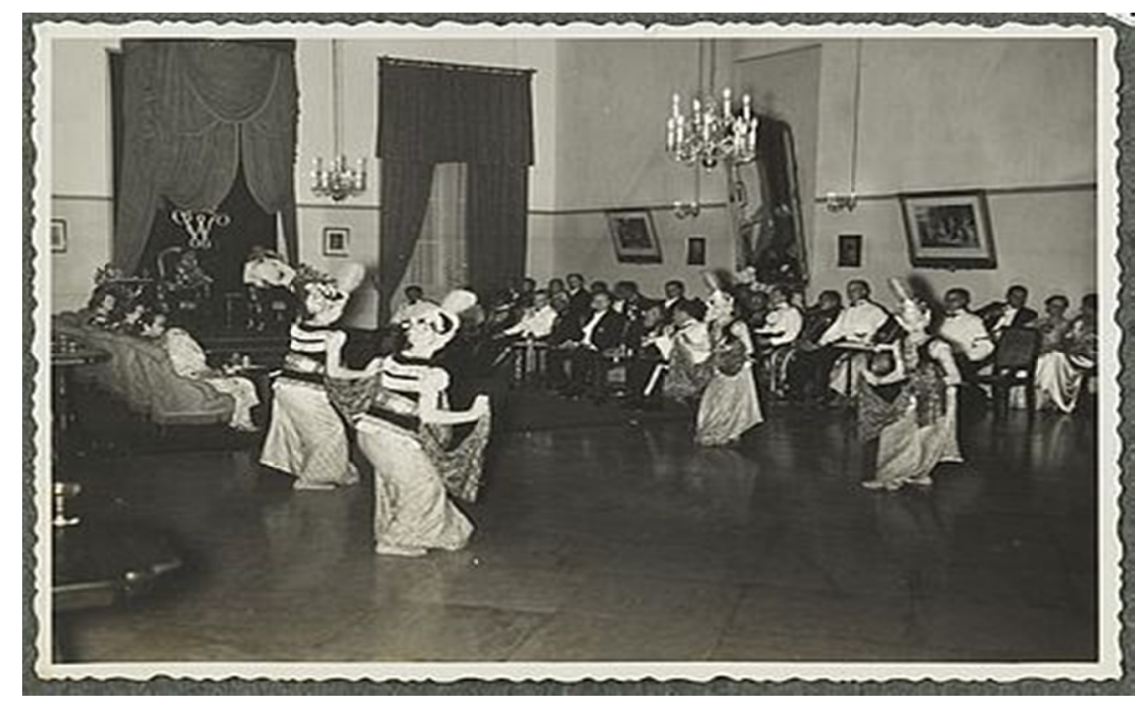

Figure 1. A photograph of Sultan Hamengku Buwana VIII dressed in General Attire while watching his favorite dance (Photo: R.M. Kaswarja, 1935. Repoduction by R.M. Pramutomo in 2006).

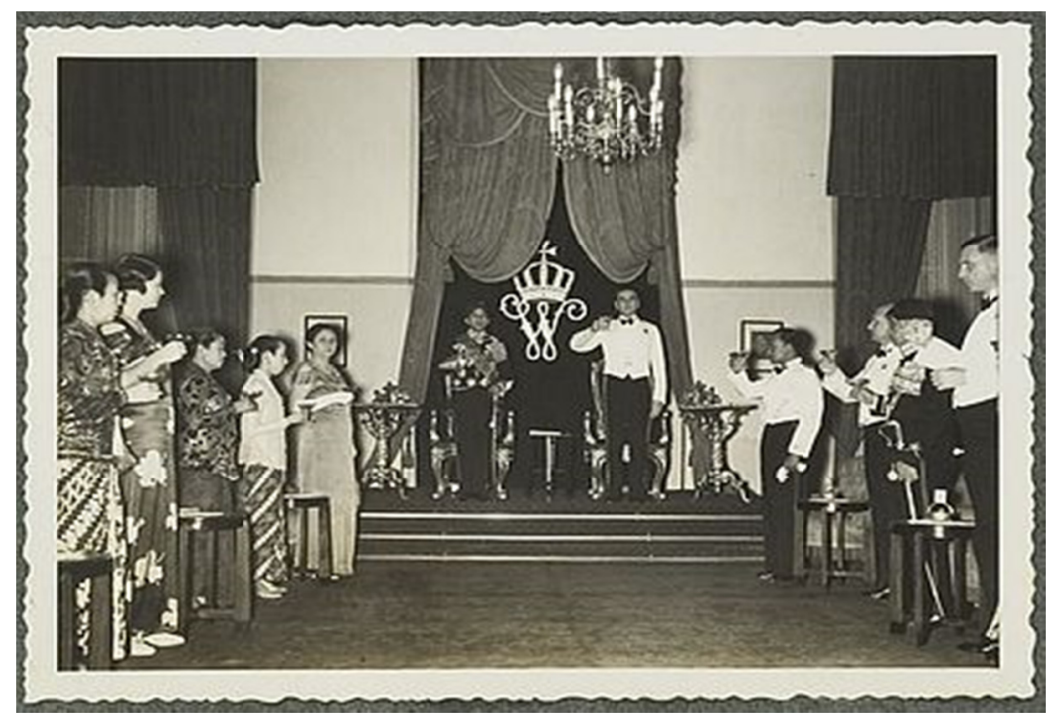

Figure 2. Sultan Yogyakarta visited to the official residence of the Governor of Yogyakarta

(F o t o: R.M.Kaswarja, 1934. Reproduction by Pramutomo years 2006). 


\section{Conclusion}

Placing the perspective of the fashion process for fashion and its relation to ceremonialism and performance art in Yogyakarta Palace is a historicity in itself. The pattern of regularity which was started from an etiquette penetration and state procedures among the elites at that time was crucial for the implementation of the fashion process. A new tradition was finally born as a trigger for ceremonialism accompanied by events of the performing arts. The tedhak loji event finally transformed into a new tradition that lasted until 1941, when Sultan Hamengku Buwana IX was the top status in the Sultan's Palace in Yogyakarta.

In the context of ceremonialism and the events of the performing arts, the new tradition of loyah established by the era of Sultan Hamengku Buwana III (1812-1814) has become an arena of status display. Clothing as a fashion process is exhibited in clothing for comfort, clothing for modesty, and clothing for display patterns. The elaboration of this fashion process is also attributively beginning to be established through differences in accessories and rank attributes from the top of the hierarchical status of the Sultan, the Princes, the Patihs, the Regents, to the traditional officials below. In turn, this dress etiquette also leads to the impact of the seating position and clothing rules imposed when watching the performing arts in the Sultan's Palace or in the official residence of the Governor or Resident of Yogyakarta.

\section{References}

Arsip Kagungan Dalem kawontenanipun serat-serat Ingkang Sinuwun kaping pitu, No. W 170/H 47, W 171/H48/dan W 172/H49; Collection of Puraraksa

Arsip No. W 25 angka 298, Collection of Puraraksa Kraton Yogyakarta.

Arsip No. W 289, Collection of Widya Budaya Kraton Yogyakarta.

Babad Mentawis Ngayogyakarta, No. A 38 (Collection of Widya Budaya).

Babad Ngrengreng Kaping Kalih t.t. (Collection of Universitas Indonesia, Jakarta).

Bendhelan Pranatanipoen Lenggah Mahargya Goepernoer Jenderal Tjarda van Ngayogyakarta taoen 1937.Collection of Pusat Kajian Arsip dan Dokumen KRT. Wiroguno

Cathetan Bab Abdi Dalem Prajurit, No. W 229 a, W 229 b, dan W 229 c. Collection of Widya Budaya Kraton Yogyakarta. Starkenborgh-Strachouer Ing Karaton

Geertz, C. (1980). Negara: The Theatre State in Nineteenth-Century Bali. New Jersey: Princeton University Press.

Hauser, A. (1979). The Sociology of Art. Terj. Kenneth J. Northcott. Chicago and London: The University of Chicago Press.

Hendriatmo, A. S. (2006). Giyanti 1755: Perang perebutan Mahkota III dan Terpecahnya Kerajaan Mataram Menjadi Surakarta dan Yogyakarta. Tangerang: CS Book.

Lindsay, J. (1991). Klasik, Kitsch, Kontemporer: Sebuah Studi Tentang Seni Pertunjukan Jawa. Yogyakarta: Gadjah Mada University Press. 
Manuskrip Ngayugyakarta Pagelaran No D 34 (Collection of Widya Budaya).

Margana, S. (2004). Kraton Surakarta dan Yogyakarta (1769-1874). Yogyakarta: Pustaka Pelajar.

Morris, D. (1977). Manwatching: A Field Guide to Human Behavior. New York: Harry N'Abrahms.

Pramutomo, R. M. (2009). Tari Seremoni, dan Politik Kolonial Volume I. Surakarta: ISI Press Solo.

Pramutomo, R. M. (2010). Tari Seremoni, dan Politik Kolonial Volume II. Surakarta: ISI Press Solo.

Ricklefs, M. C. (2003). Jogjakarta di Bawah Sultan Mangkubumi (1749-1792): Sejarah Pembagian Jawa. Terj. Hartono Hadikusuma dan Setyawati Alkhatab. (Yogyakarta: Matabangsa).

Serat Babad Momana, t.t., (Collection of Soemadidjojo Mahadewa).

\section{Notes}

Note 1. M.C. Ricklefs even assumed the need for a long process that was shown from political ethics in each period of the Sultan of Yogyakarta's administration, before the term kangjeng - which was applied in psychological and colonialism. Even up to Hamengku Buwana II (1792-1812) the term for the Resident of Yogyakarta was' brother 'or' deer heer ', then when approaching the end of Daendels' rule in Yogyakarta it was recommended to use the term' minister 'to Dutch colonial officials. This was also still carried out by Hamengku Buwana III when he ascended the throne in 1812 by mentioning 'minister' for the British colonial officials at that time; check M.C. Ricklefs, Jogjakarta Under Sultan Mangkubumi (1749-1792): History of the Distribution of Java. Terj. Hartono Hadikusuma and Setyawati Alkhatab. (Yogyakarta: Matabangsa), 2003. The Serat Babad Momana Manuscript explains the change in the title 'minister' as the official summons of the colonial officials made by Daendels, check out the Serat Babad Momana, t.t., (Soemadidjojo Mahadewa Collection), 24; check also the Babad Ngrengreng Kaping Kalih as referred to by Jennifer Lindsay, Classical, Kitsch, Contemporary: A Study of Javanese Performing Arts, (Yogyakarta: Gadjah Mada University Press, 1991).

Note 2. See Margana, Kraton Surakarta dan Yogyakarta (1769-1874). Yogyakarta: Pustaka Pelajar, 2004, 91-95.

Note 3. See Serat Babad Momana, n.d., 26, (Collection Soemadidjojo Mahadeva)

Note 4. At that time every time he saw a horse race, a resident of Yogyakarta invited the seventh Sultan by riding his magnificent carrion Kangjeng Kyahi Garudayaksa. This kind of treatment was a pattern of submissive behavior in the presence of the Resident, as the Sultan 


\section{Macrothink

had relinquished the use of his magnificent vehicle in conjunction with the Resident at that time; see also the Serat Babad Momana, t.t. (Soemadidjojo Mahadewa Collection).

Note 5. Information from official palace sources for three years in a row, from 1903-1905 the seventh Sultan received a state visit from three foreign guests, namely from the brother-in-law of King Wilhelmina in the Netherlands, then a Hindu king (possibly from India), and an Italian nobleman, with each held a banquet at Yogyakarta Palace and presented a complete performing art both dances and Western music played by Europeans and natives in turn; check also the Archive of the Kagungan Dalem kawontenanpun serat Ingkang Sinuwun kaping pitu, No. W 170 / H 47, W 171 / H48 / and W 172 / H49; See also Serat Babad Momana, t.t. (Mahadewa Soemodidjojo Collection.). Transliteration and translation. Pramutomo, 101. It is stated in this literature, "... 25 Sawal, Bé 1832, son of king Ditsalan who was appointed by the Duke of Duke, was Queen Nerderlan's daughter-in-law to the State of Peace, ... to New York, and to the entrance of the Palace, with the uncertainty of the surgery and the extra ringgit of fellow men. ... in the year 1834, the Prince of Italy visited the country of Yogyakarta, including the Embassy in peace and security. " (... 25 [months] Early in the year 1832 A.J. or January 25, 1903 A.D., Son of King Ditsalan who is the Crown Prince and also the sister-in-law of Raja Putri Nederlan came to visit Yogyakarta, to stay at the residence of the Resident, ... 19 [months] Shawwal year of Wawu 1833 A.J. or January 11, 1904 A.D., Raja Hindu (India?), came to visit Yogyakarta, after entering the inner palace, the art of performing the bedhaya dance and wayang wong four rounds. ... in 1834 A.J. or January 1905 A.D., Prince of Italy came to visit Yogyakarta and also visited the inner palace, and presented the art of Bedhaya and Srimpi.

Note 6. See Desmond Morris in Manwatching: A Field Guide to Human Behaviors, (New York: Harry N'Abrahms, 1977), 6-23.

Note 7. See Morris, 23-24.

Note 8. Geertz, 1980, 13.

Note 9. Geertz, 1980, 13-14.

Note 10. Geertz, 126.

Note 11. Geertz, 127.

Note 12. Geertz 124-128.

Note 13. Manuscript of Ngayugyakarta Pagelaran, Collection of Widya Budaya called the Sultan HB IV as the reformer fashion servants soldier after status of Kratton soldier changes of position as a warrior functional to ceremonial soldiers.

Note 14. Concerning the situation of soldiers serving up to the time of the fourth Sultan, can be seen in Ngayugyakarta Pagelaran, No. D 34 (Widya Budaya Collection). In this source there is also the name of the accompaniment song and the name of the flag and the dwaja of each unit or bregada. 
Note 15. Babad Mentawis Ngayogyakarta, No. A 38 (Widya Budaya Collection). In fact, according to this source, the trail trail of banon (kicking bricks) is a tradition that is preserved at every Grebeg Mulud Dal year to commemorate the Mangkunegara I attack when Sultan Hamengku Buwana I was in the Great Mosque after listening to the recitation of the birth of the Prophet Muhammad at that time, so this continues to be preserved every Grebeg Mulud Dal year.

Note 16. The concept of status display is referred to from Desmond Morris, Manwatching: A Field Guide to Human Behavior (New York: Harry N'Abrahms, 1977), 6-23. In one flag there is a rank hierarchy. Each rank status has a very unique marker attribute. Even the status of a unitary leader called Panji is often shown through special dance movements, such as the Panji Dhaèng, who performed the Makajar dance, the Langenastra the spear section that brought tayungan, and the Sumaatmaja sword shield section to the Nyutra unity in the ndadhap tribute of the Langenastra Warriors who used to wear sampur. cindhe. Likewise, the Nyutra section of Trunajaya (tumbak) warriors also wear cindhe sampur, which is said to have used cindhe sampur for the Trunajaya Nyutra section related to magical power when in charge of opening a tiger cage to be pitted with a bull in Alun-alun for an attraction.

Note 17. Literally the meaning of the name sampeyan dalem is the feet of the Sultan.

Note 18. See Serat Babad Momana tt. (Soemadidjojo Mahadewa Collection), 23. Initially only the Mantrijero unit and the Ketanggung unit received European-style fashion designs, but gradually all the army soldiers got European-style fashion designs.

Note 19. Ngayugyakarta Pagelaran Nomor D 34, Collection of Widya Budaya, 189.

Note 20. Ngayugyakarta Pagelaran Nomor D 34, Collection of Widya Budaya.

Note 21. Serat Babad Momana Momana n.d. 22-23, (Collection of Soemadidjojo Mahadeva).

Note 22. See Serat Babad Momana, n.d. 23 (Collection of Soemadidjojo Mahadeva).

Note 23. On the Serat Babad Momana, t.t. 24-25 explained that the change in clothing design for the members of the Ketanggung and Mantrijero warriors was one of the Sultan's efforts in adopting Western elements in the military area.

Note 24. Compare this with Arnold Hauser's statement about elite territory categorized in the art of the cultural elite; see, Arnold Hauser The Sociology of Art. Translation by. Kenneth J. Northcott (Chicago and London: The University of Chicago Press, 1979), 549-550.

Note 25 . Geertz clearly mentions the status of priests in the 19th-century Bali ceremony as ... the priest as the king's jewel ...; check Geertz, 1980, 130. This is what strengthens Geertz's assumption, that political 'drama' in Bali is interpreted as sacred 'drama'. While in the Sultan's Palace, political drama is the meaning of politics itself. The clearest evidence is the palace amparan ceremony which is always brought along in the Tedhak Loji incident.

Note 26. The original royal throne used by the throne of the Sultan of Yogyakarta (since the first ruler of the Kingdom of Yogyakarta) has been honored at the tomb of the king of Imogiri of the Besiyaran Palace (where Sultan Hamengku Buwana IV is buried). The present throne 
is a replica of the time of Sultan Hamengku Buwana V. Also see R.M. Pramutomo, Tari, Seremoni dan Politik Kolonial Volume I (Surakarta: ISI Press Solo, 2009), 56-61)

Note 27. Babad Ngreng Ngreng Kaping Kalih t.t. (Collection of Indonesian University) informs the preparations from the menu to the dress worn by the Sultan and the dancers who will be performing at that time.

Note 28. This honor star was first worn by Sultan Hamengku Buwana IV when it was crowned in 1816. Until now this honorary star is considered an heirloom by the Sultan in Yogyakarta, and is always embedded in every coronation of the new Sultan.

\section{Copyright Disclaimer}

Copyright reserved by the author(s).

This article is an open-access article distributed under the terms and conditions of the Creative Commons Attribution license (http://creativecommons.org/licenses/by/3.0/). 